\title{
Identification of micro-RNA expression profile related to recurrence in women with ESMO low-risk endometrial cancer
}

\author{
Tiphaine de Foucher ${ }^{1}$,, Maria Sbeih ${ }^{1}$, Jenifer Uzan³ ${ }^{3}$ Sofiane Bendifallah²,4,8, Marine Lefevre ${ }^{5}$, \\ Nathalie Chabbert-Buffet ${ }^{1,2,8}$, Selim Aractingi ${ }^{1,6}$, Catherine Uzan ${ }^{7,8}$, Issam Abd Alsalam ${ }^{9}$, Rana Mitri ${ }^{9}$, \\ Romain H. Fontaine ${ }^{1}$, Emile Darai ${ }^{1,2,8}$, Bassam Haddad ${ }^{3}$, Céline Méhats $^{10}$, Marcos Ballester ${ }^{1,2,8}$, \\ Geoffroy Canlorbe $e^{1,7,8^{*}+}$ and Cyril Touboul ${ }^{3,11+}$
}

\begin{abstract}
Background: Actual European pathological classification of early-stage endometrial cancer (EC) may show insufficient accuracy to precisely stratify recurrence risk, leading to potential over or under treatment. Micro-RNAs are post-transcriptional regulators involved in carcinogenic mechanisms, with some micro-RNA patterns of expression associated with EC characteristics and prognosis. We previously demonstrated that downregulation of micro-RNA-184 was associated with lymph node involvement in low-risk EC (LREC). The aim of this study was to evaluate whether micro-RNA signature in tumor tissues from LREC women can be correlated with the occurrence of recurrences.

Methods: MicroRNA expression was assessed by chip analysis and qRT-PCR in 7 formalin-fixed paraffin-embedded (FFPE) LREC primary tumors from women whose follow up showed recurrences (R+) and in 14 FFPE LREC primary tumors from women whose follow up did not show any recurrence $(R-)$, matched for grade and age. Various statistical analyses, including enrichment analysis and a minimum p-value approach, were performed.

Results: The expression levels of micro-RNAs-184, -497-5p, and -196b-3p were significantly lower in R+ compared to $R-$ women. Women with a micro-RNA-184 fold change $<0.083$ were more likely to show recurrence $(n=6 ; 66 \%)$ compared to those with a micro-RNA-184 fold change $>0.083(n=1 ; 8 \%), p=0.016$. Women with a micro-RNA-196 fold change $<0.56$ were more likely to show recurrence $(n=5 ; 100 \%)$ compared to those with a micro-RNA-196 fold change $>0.56(n=2 ; 13 \%), p=0.001$.
\end{abstract}

Conclusions: These findings confirm the great interest of micro-RNA-184 as a prognostic tool to improve the management of LREC women.

Keywords: Low risk endometrial cancer, Recurrence, MicroRNAs, MicroRNA-184

\footnotetext{
*Correspondence: geoffroy.canlorbe@aphp.fr

${ }^{\dagger}$ Geoffroy Canlorbe and Cyril Touboul contributed equally to this work

${ }^{7}$ Department of Surgery and Oncological Gynaecology, Pitié-Salpétrière University Hospital, Assistance Publique des Hôpitaux de Paris, Sorbonne University, Paris, France

Full list of author information is available at the end of the article
} 


\section{Background}

Endometrial cancer (EC) is the most common gynecologic cancer in women in developed countries. The highest estimated incidences in 2012 are in the USA and Canada $(19.1 / 100,000)$ and northern $(12.9 / 100,000)$ and Western Europe $(15.6 / 100,000)[1,2]$. It is also the 14th cancer in terms of mortality accounting for 76,000 deaths/year worldwide [1]. The most frequently occurring histologic subtype is endometrioid adenocarcinoma, with a good prognosis [3]. Women are diagnosed at an early stage (stage I of the International Federation of Gynecology and Obstetrics (FIGO) classification) in $75 \%$ of the cases, when the disease is still confined to the uterus.

Among various risk stratification systems, the European Society for Medical Oncology (ESMO) system, with its four risk groups classification for early stage EC, provides the highest discrimination for both recurrence free survival (RFS) and the risk of nodal metastases [4]. However, it shows insufficient accuracy to accurately stratify recurrence risk in women with early-stage EC, as their recurrence rates range from 2 to $26 \%$ depending on several epidemiological and histological factors [5]. Thus, additional tools are needed to promote a more individualized management of early-stage EC women. In this perspective, a growing number of studies are focusing on the key role of genetics and molecular biology in EC [6].

Micro-RNAs are short non-coding RNA, 22 nucleotides in length, which work at post-transcriptional level as epigenetic regulators. They can inhibit the translation process, or initiate the process of mRNA degradation [7]. They are implied in numerous process including carcinogenesis [8], where they act as tumor suppressors or activators (onco-miRs). Several micro-RNA profiles have been described in EC, in particular related to histopathological characteristics and prognosis of the tumor $[9,10]$. Especially, down regulation of micro-RNA-184, and $-34 c-5 p$, involved in epithelial to mesenchymal transition (EMT), have recently been linked to the lymph node involvement in women with early-stage grade 1 and 2 EC [11]. They can be easily detected in FFPE carcinogenic specimens [12], which opens new opportunities to develop accurate diagnosis tools for tumor staging. However, few data are available about micro-RNA profiles and recurrences in low-risk EC (LREC).

\section{Methods}

The aim of this study was to evaluate whether microRNA profile from LREC women can be correlated with the occurrence of recurrences and used as a tool to adapt therapeutic management.

Many of the methods related to our patient cohort, micro-RNA extraction, microarray hybridization and analysis, qRT-PCR, and minimal p-value approach have been previously published $[10,11]$.

\section{Experimental design}

Approval for the present study was obtained from the local Medical Ethics Committee (CPP Ile-de-France X; 2015-01-03).

The experimental design for profiling changes in microRNA according to the occurrence of recurrence in LREC FFPE primary tumor specimens is shown in Fig. 1. We included seven women, with initial LREC, who presented with histologically proven recurrences $(\mathrm{R}+)$ during their follow up between January 2000 and October 2014 in Créteil University Hospital and Tenon University Hospital. Their characteristics are summarized in Table 1.

According to the ESMO-ESGO-ESTRO classification, low-risk group included FIGO Stage I endometrioid carcinoma, histological grade $1-2,<50 \%$ myometrial involvement, lympho vascular space involvement (LVSI) negative tumors. They all had disease free pelvic lymph nodes. Women underwent primary surgical treatment (including total hysterectomy, bilateral salpingo-oophorectomy, and systematic nodal staging with optional adjuvant brachytherapy according to French guidelines. Each one of them was matched according to histologic grade (grade 1 or grade 2) and age with two women without any recurrence $(\mathrm{R}-)$, who were used as control subjects. The exclusion criteria were as follows: Lynch syndrome (the search for a loss of expression of one of the Mismatch Repair proteins by immunohistochemistry and for tumor instability (microsatellite instability replication error repeats phenotype) were performed when EC occurred before the age 50 years or when there was a suggestive family history) and refusal of consent.

Data of women included in the study were retrospectively abstracted from prospectively maintained databases. They included age, parity, body mass index (calculated as weight in kilograms divided by the square of height in meters), comorbidities (diabetes, dyslipidemia), 2009 FIGO stage, histologic type and grade, depth of myometrial involvement, LVSI status, and time between surgery and sample analysis.

Their follow-up was conducted every 3 months for the first 2 years, every 6 months for the following 3 years, and once a year thereafter. It consisted of physical examinations, and the use of imaging techniques or histological biopsies according to the findings. Recurrences were defined according to previous reports [13]: local recurrence was defined by a vaginal vault location; central pelvic recurrence was defined by a location within the pelvis but with no involvement of the vaginal vault or of the pelvic nodes, nodal recurrence included pelvic and/or para aortic nodal 


\begin{tabular}{|ll|}
\hline Inclusion criteria & Exclusion criteria \\
- Primary surgical treatment for EC with total & - Lynch syndrome \\
hysterectomy and systematic nodal staging & - Refusal to consent \\
- ESMO low risk EC & \\
\hline No metastatic pelvic lymph node & \\
\hline
\end{tabular}

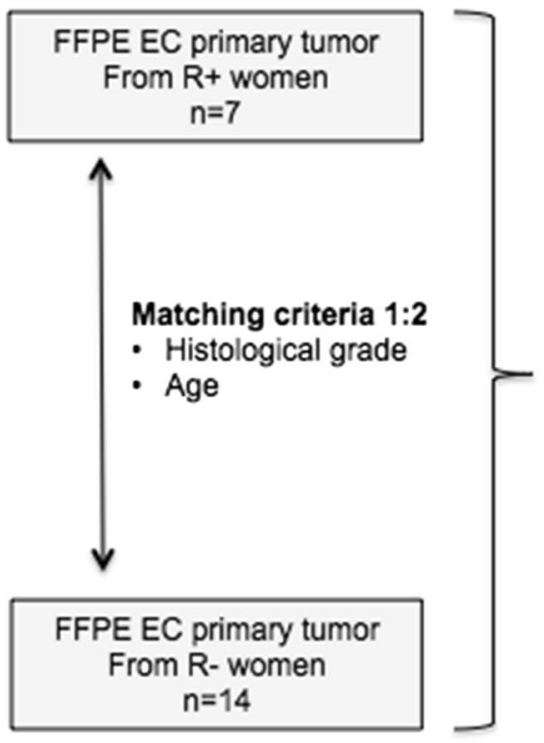

\begin{tabular}{|c|}
\hline $\begin{array}{l}\text { Micro-RNA screening phase } \\
\text { Material: hybridization on miRNA } 4.0 \text { chips } \\
\text { (Affymetrix) } \\
\text { Samples: } 7 \text { (FFPE EC primary tumor from R+ } \\
\text { women) vs. } 14 \text { (FFPE EC primary tumor from R- } \\
\text { women) } \\
\text { Statistical analysis: microarray analysis ( } p \text {-value } \leq \\
0.05 \text { and variation }>2 \text { ); enrichment analysis } \\
\text { Validation by RT-qPCR }\end{array}$ \\
\hline$\downarrow$ \\
\hline $\begin{array}{l}\text { Analysis of } 6 \text { candidate micro-RNAs } \\
\text { Material: RT-qPCR } \\
\text { Samples: } 7 \text { (FFPE EC primary tumor from R+ } \\
\text { women) vs. } 14 \text { (FFPE EC primary tumor from R- } \\
\text { women) } \\
\text { Statistical analysis: Mann-Withney test; minimal p- } \\
\text { value approach; Fisher test }\end{array}$ \\
\hline
\end{tabular}

Fig. 1 Flowchart describing the constitution of groups and the experimental design. EC endometrial cancer, ESMO European Society of Medical Oncology, FFPE formalin-fixed paraffin-embedded, $R+$ women whose follow up showed recurrence, $R$ - women whose follow up showed no recurrence, $R T$ reverse transcription, $q P C R$ quantitative real time polymerase chain reaction

Table 1 Histological characteristics of LREC women with recurrences

\begin{tabular}{lllllll}
\hline Women & $\begin{array}{l}\text { Histological } \\
\text { grade }\end{array}$ & FIGO stage & LVSI status & Nodal status & RFS (months) & Localization of recurrences \\
\hline 1 & 1 & IA & Neg & $15 \mathrm{~N}-/ 15$ & 10 & Local \\
2 & 1 & IA & Neg & $12 \mathrm{~N}-/ 12$ & 34 & Local \\
3 & 1 & IA & Neg & $7 \mathrm{~N}-/ 7$ & 114 & Centro pelvic \\
4 & 1 & IA & Neg & $17 \mathrm{~N}-/ 17$ & 37 & Local \\
5 & 1 & IA & Neg & $6 \mathrm{~N}-/ 6$ & 15 & Nodal (PA) and centro pelvic \\
6 & 2 & IA & Neg & $26 \mathrm{~N}-/ 26$ & 13 & Centro pelvic \\
7 & 1 & IA & Neg & $13 \mathrm{~N}-/ 13$ & 5 & Distant (liver) and centro pelvic \\
\hline
\end{tabular}

LREC low risk endometrial cancer, FIGO International Federation of Gynecology and obstetric, LVSI lymphovascular space invasion, RFS recurrence free survival, $P A$ para-aortic

locations; distant recurrence included distant metastasis (bone, liver, lung and brain). RFS was defined as the length of time from the date of primary surgery to any EC recurrence, and was censored at date of last followup or at date of death without recurrence.
RNA extraction from FFPE tissues

For each woman, total RNA was extracted using the micro-RNAeasy FFPE Kit (Qiagen, Courtaboeuf, France), according to the manufacturer's instructions. 
Briefly, FFPE tissues were obtained from the hysterectomy specimens. FFPE tissue blocks were sectioned on a standard microtome (Leica-microsystems RM 2145) to generate successive $10 \mu \mathrm{m}$ sections. A pathologist evaluated each slide, and regions of invasive carcinoma were confirmed and marked. For each sample, marked regions from several slides (number depending on the size of the invasive area, according to the manufacturer's instructions) were microdissected using a new sterile blade, and the dissected tissues were placed immediately into an RNase-free microcentrifuge tube. After a deparaffinization step, the tissues were digested with protease and treated with DNase. After washing, the RNA, including the small micro-RNA fraction, was eluted with $20 \mu$ distilled water. The concentrations and quality of the RNA recovered were measured using the Nanodrop 1000A spectrophotometer (Nanodrop Technologies, Wilmington, DE, USA). The median ratio of $260 / 280$ was 1.85 (interquartile range (IQR): $1.70-1.91)$ and the median concentration was $143 \mathrm{ng} / \mu \mathrm{l}$ (IQR: 91-378).

\section{Microarray hybridization (GEO: GSE100078) and data analysis}

Microarray analysis was conducted on 21 distinct specimens: 7 specimens from $\mathrm{R}+$ women, each one of them matched with 2 specimens from $\mathrm{R}$ - women. Microarray hybridization on Micro-RNA 4.0 chips (Affymetrix) was conducted at the genomic platform of the Institut Cochin, Paris. After validation of the RNA quality with Bioanalyzer 2100, $1 \mu \mathrm{g}$ of total RNA was biotin labeled following the FlashTag Biotin HSR RNA labeling kit (Affymetrix).

After overnight hybridization, the Micro-RNA 4.0 chips were washed in the Fluidic Station FS450 (Affymetrix) following a specific protocol and scanned using the GCS3000 7G. The scanned images were then analyzed with Expression Console software (Affymetrix) to obtain raw data (CEL files) and metrics for Quality Control. No apparent outliers were detected. Specific microRNA analysis was performed using Partek Flow software, version 3.0 Copyright, 2014 (Partek Inc., St Louis, MO, USA). CEL files were imported and normalized using robust multi-array averaging.

Micro-RNAs detected with a variation of at least 2, and with a nominal $\mathrm{p}$-value $\leq 0.05$, between $\mathrm{R}+$ and $\mathrm{R}-$ women were considered to be differentially expressed, and thus selected for further analysis.

\section{Validated target gene and enrichment analysis}

To estimate the biologic effects of the differentially expressed micro-RNAs, lists of validated target genes were determined using currently available databases, including Tarbase ${ }^{\circledR}$ and Mirtarbase ${ }^{\circledR}$. Gene Ontology
(GO) enrichment analysis was performed on the lists using Enrichr [14, 15].

\section{Validation of candidate micro-RNAs with Reverse Transcription (RT) and Quantitative Real-Time PCR (qRT- PCR)}

One microgram of total RNA was used in all RT reactions that were performed with the miScriptII ${ }^{\circledR} \mathrm{RT}$ Kit, using the $5 \times$ miScript HiSpec Buffer method, according to the manufacturer's instructions (Qiagen) with a Thermo Hybaid PXE 0.2 Thermal Cycler. Complementary DNA samples were stored at $-20^{\circ} \mathrm{C}$ for further use.

Micro-RNA expression was analyzed by real-time PCR using miScript SYBR Green PCR Kit (Qiagen) according to the manufacturer's instructions, with an initial activation step at $95^{\circ} \mathrm{C}$ for $15 \mathrm{~min}$, followed by 50 cycles of $94{ }^{\circ} \mathrm{C}$ for $15 \mathrm{~s}, 55^{\circ} \mathrm{C}$ for $34 \mathrm{~s}$, and $70{ }^{\circ} \mathrm{C}$ for $30 \mathrm{~s}$. A final melting curve analysis was performed to verify that a single product was amplified. All steps were performed in duplicate using an Applied Biosystems ${ }^{\circledR} 7300$. The results are expressed as $\mathrm{Ct}$ values and normalized on the calculated median $\mathrm{Ct}$ of each sample $(\Delta \mathrm{Ct})$. Micro-RNA primers were from Qiagen. Relative expression was calculated using the comparative Ct method $\left(2^{-\Delta \Delta \mathrm{Ct}}\right)$. SNORD68, SNORD61, and RNU6 were used as endogenous controls for data normalization $[10,11]$.

For the results from the qRT-PCR on micro-RNA expression, data are expressed as mean \pm sem. Means between two groups were compared using the MannWhitney test. $\mathrm{p}<0.05$ was considered to be statistically significant. GraphPad Prism version 7 was used for analysis of tissue samples (GraphPad Software, La Jolla, CA, USA).

\section{Optimal micro-RNA fold-change cutoffs correlated with occurrence of recurrence}

For qualitative analysis, we calculated optimal cut-offs for each micro-RNA to correlate semi-quantitative expression and the occurrence of recurrence. The optimal foldchange cut-off was determined by a minimum $\mathrm{p}$-value approach.

\section{Statistical analysis}

Unless otherwise specified, data were managed with an Excel database and analyzed using R 3.1.3 software, available online.

\section{Results}

Clinical and pathological characteristics

The clinical and pathologic variables of the women are shown in Table 2.

The median age was 66 years (interquartile range (IQR): $57-76$ ) in the $\mathrm{R}+$ group and 60 years (IQR: $45-82$ ) 
Table 2 Epidemiologic and histologic characterizations between low risk EC women with and without recurrences

\begin{tabular}{|c|c|c|c|}
\hline & $\begin{array}{l}\text { EC FFPE primary tumor no recurrence, } \\
N=14\end{array}$ & $\begin{array}{l}\text { EC FFPE primary tumor recurrences, } \\
\mathrm{N}=7\end{array}$ & p-value \\
\hline Age, median (IQR) & $60(45-82)$ & $66(57-76)$ & 0.45 \\
\hline Diabetes n (\%) & $1(7 \%)$ & $1(14 \%)$ & 1 \\
\hline Dyslipidemia n (\%) & $2(14 \%)$ & $1(14 \%)$ & 1 \\
\hline Parity, median (IQR) & $2(0-5)$ & $2(1-4)$ & 0.93 \\
\hline BMI, median (IQR) & $28(18-39)$ & $26(23-36)$ & 0.60 \\
\hline Histologic grade, $n(\%)$ & & & 1 \\
\hline Grade 1 & $12(85 \%)$ & $6(85 \%)$ & 0.70 \\
\hline Grade 2 & $2(15 \%)$ & $1(15 \%)$ & \\
\hline Tumor size (mm), median (IQR) & $16(5-50)$ & $35(9-45)$ & \\
\hline $\begin{array}{l}\text { Time between surgery and sample analysis (months), } \\
\text { median (IQR) }\end{array}$ & $165(94-204)$ & $137(59-202)$ & 0.52 \\
\hline Vaginal brachytherapy after surgery & $10(71 \%)$ & $2(28 \%)$ & 0.16 \\
\hline
\end{tabular}

$E C$ endometrial cancer, FFPE formalin-fixed paraffin-embedded, IQR interquartile range, $B M I$ body mass index

in the $\mathrm{R}$ - group $(\mathrm{p}=0.45)$. The two groups were comparable for histologic grade and tumor size. Furthermore, the comorbidities (diabetes and dyslipidemia), parity and body mass index did not differ between $\mathrm{R}+$ and $\mathrm{R}-$ women. Neither did the treatment modalities. The median time between surgery and sample RNA extraction was 165 months (IQR: 94-204) in the R- group and 137 months (IQR: 59-202) in the $\mathrm{R}+$ group $(\mathrm{p}=0.52)$.

\section{Distinct micro-RNA signatures of LREC from $\mathrm{R}+$ women}

We focused our study on the 2578 probes containing sequences for mature micro-RNAs. As illustrated by the volcano plot representation (Fig. 2), there was more than a 2-fold change (FC) significant difference in the normalized fluorescence intensity of 6 of these microRNAs between the $\mathrm{R}+$ and the $\mathrm{R}-$ groups: 5 microRNAs (micro-RNA-184, -497-5p, 195-5p, -7162-3p, and -196b-3p) had a decreased expression and one (microRNA-6080) had an increased expression in samples from the $\mathrm{R}+$ group compared the $\mathrm{R}-$ group (Table 3 ).

We extracted from the micro-RNA databases the known validated targets of the micro-RNAs exhibiting at least a 2-FC, with significant value $(\mathrm{p}<0.05)$, in the LREC tumors from $\mathrm{R}+$ women vs. $\mathrm{R}-$ women: it displays 813 genes, with the majority associated with micro-RNA-497 and micro-RNA-195. Genes involved in PI3 kinase signaling pathway, cancer and cell cycle checkpoint were specifically enriched for these two micro-RNAs. In addition, micro-RNA-7162 and micro-RNA-184 were associated with telomerase maintenance and DNA replication, micro-RNA-6080 with RNA processing, and microRNA-196b with endometrial cancer and MAPK/cdk5 (Fig. 3).

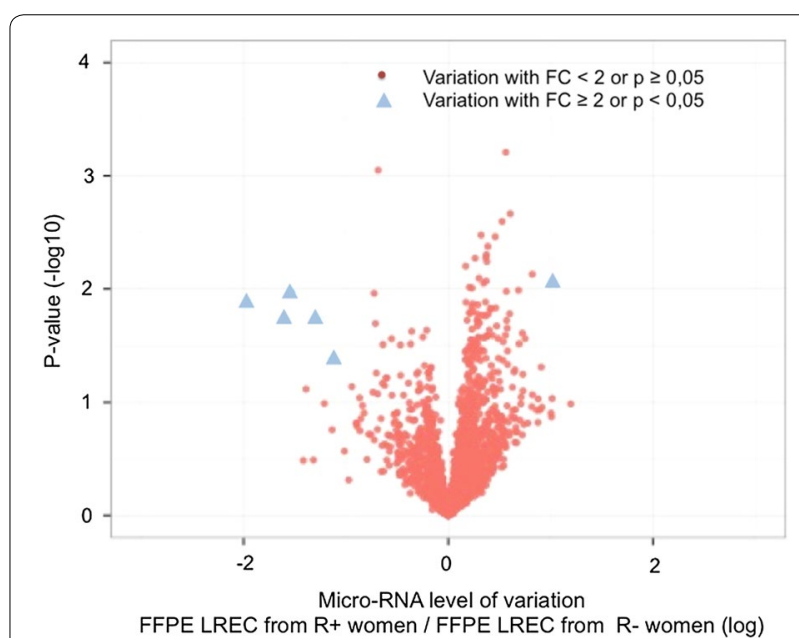

Fig. 2 Volcano plot. Abscissa is the logarithmic value of the level of variation (LogRatio) and ordinate is the negative logarithm of the statistical value $(-\log (p))$ of fluorescence intensities of the hybridized probes from $\mathrm{R}+$ or $\mathrm{R}-$ samples. There was more than a 2 -fold change in normalized fluorescence intensity of 6 micro-RNAs (blue triangle) between $R+v s$. $R-$ groups $(p<0.05)$ : 5 decreased in intensity (on the left) and 1 increased in intensity (on the right). FC fold Change, FFPE formalin-fixed paraffin-embedded, $L R E C$ low risk endometrial cancer, $R+$ women whose follow up showed recurrence, $R$ - women whose follow up showed no recurrence

\section{Evaluation of micro-RNA expression by real-time qRT-PCR analysis}

A qRT-PCR assay was used to confirm the expres-sion of the selected micro-RNAs. The expression levels of 3 micro-RNAs (micro-RNA-184, -497-5p and -196b$3 p)$ were significantly lower in the $\mathrm{R}+$ group compared to those in the $\mathrm{R}$ - group. The expression levels of the 6 micro-RNAs of interest are shown in Fig. 4. 
Table 3 List of the down regulated and up regulated micro-RNAs

\begin{tabular}{|c|c|c|c|c|c|}
\hline \multicolumn{3}{|c|}{ Down regulated micro-RNA } & \multicolumn{3}{|c|}{ Up regulated micro-RNA } \\
\hline Name & Fold change & p-value & Name & Fold change & $p$-value \\
\hline Micro-RNA-184 & -3.91 & 0.013 & Micro-RNA-6080 & 2.03 & 0.009 \\
\hline Micro-RNA-497-5p & -3.04 & 0.019 & & & \\
\hline Micro-RNA-195-5p & -2.90 & 0.011 & & & \\
\hline Micro-RNA-7162-3p & -2.45 & 0.019 & & & \\
\hline Micro-RNA-196b-3p & -2.18 & 0.041 & & & \\
\hline
\end{tabular}

Fold change $<-2$, p-value $<0.05$ and fold change $>2$, p-value $<0.05$, between FFPE LREC tumors from R+ patients vs. FFPE LREC tumors from $R-$ patients $F C$ fold change, FFPE formalin-fixed paraffin-embedded, $L R$ low risk, $E C$ endometrial cancer, $R+$ women whose follow up showed recurrence, $R-$ women whose follow up showed no recurrence

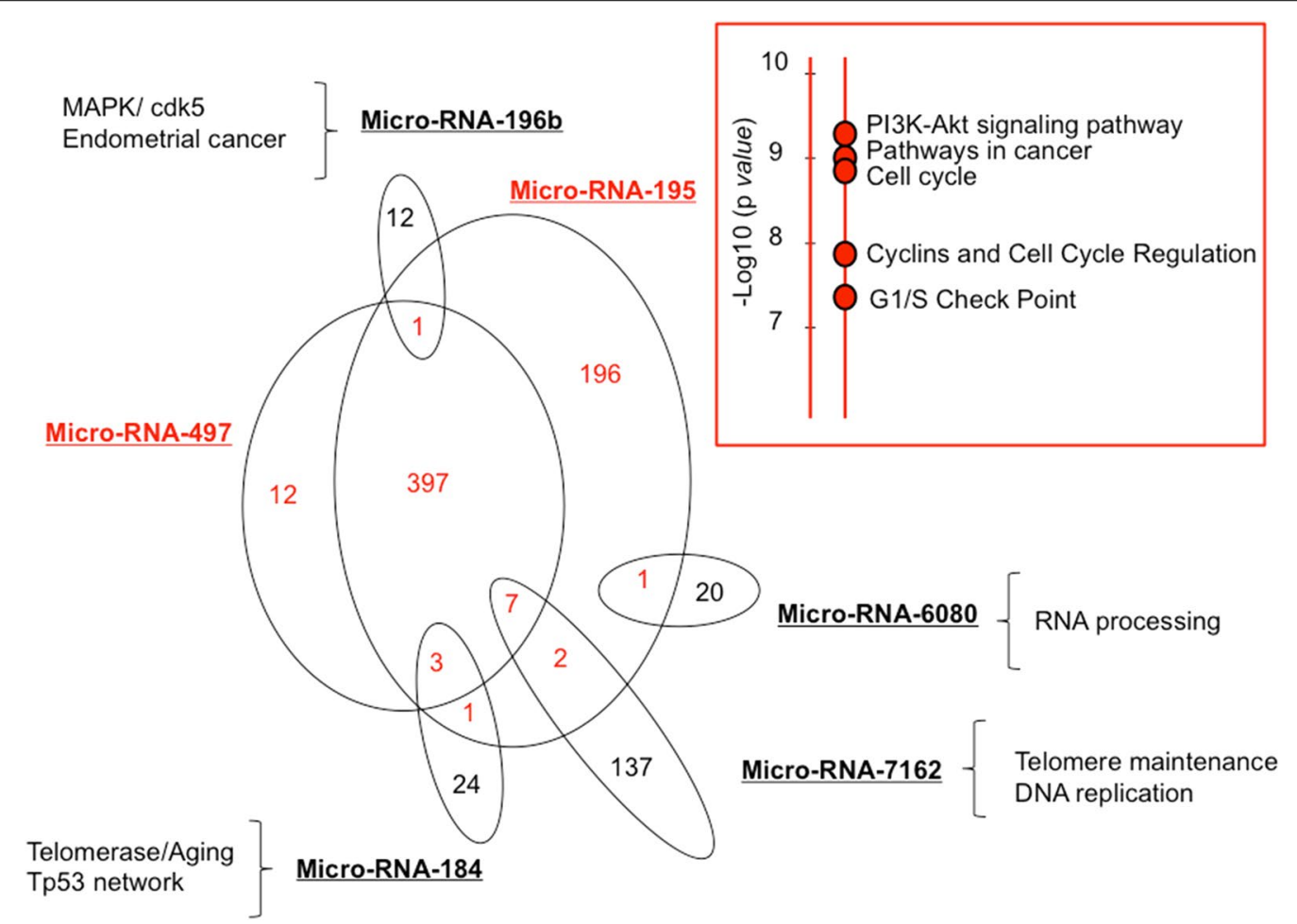

Fig. 3 Venn diagram. It represents overlap of known validated targets for the Micro-RNAs exhibiting at least a two fold change, with a significant value $(p<0.05)$, in the LREC FFPE tumors from $R+$ patients enrichment analysis. Gene ontology enrichment analysis was performed with Enrichr. In insert, $\mathrm{GO}$ analysis for the common genes in red, sorted based on - $\log _{10}(p$ value). FFPE formalin-fixed paraffin-embedded, LREC low risk endometrial cancer, $R+$ women whose follow up showed recurrence, $R-$ women whose follow up showed no recurrence

\section{Correlation between micro-RNA expression and recurrence in LREC}

Optimal cut-offs relevant to the strongest correlation between quantitative expression of the micro-RNAs that had been selected from the previous step and the occurrence of recurrence in LREC women are summarized in Fig. 5. The FC cut-offs defined were $0.083,0.45,0.58$ and 0.56 for micro-RNA-184, -497-5p, 195-5p, and microRNA $-196 b-3 p$ respectively. We compared recurrence status according to the cut-offs previously determined: women with EC and a micro-RNA-184 FC $<0.083$ were more likely to show recurrence $(n=6 ; 66 \%)$ compared to those with an micro-RNA-184 FC $>0.083 \quad(\mathrm{n}=1$; $8 \%$ ), $\mathrm{p}=0.016$; Women with EC and a micro-RNA-497 $\mathrm{FC}<0.45$ were more likely to show recurrence $(\mathrm{n}=4$; $80 \%)$ compared with those with a micro-RNA 497 FC $>0.45(\mathrm{n}=3 ; 19 \%), \mathrm{p}=0.025$; women with a microRNA-196 FC $<0.56$ were more likely to show recurrence $(\mathrm{n}=5 ; 100 \%)$ compared to those with a micro-RNA-196 $\mathrm{FC}>0.56(\mathrm{n}=2 ; 13 \%), \mathrm{p}=0.001$ (Table 4$)$. 

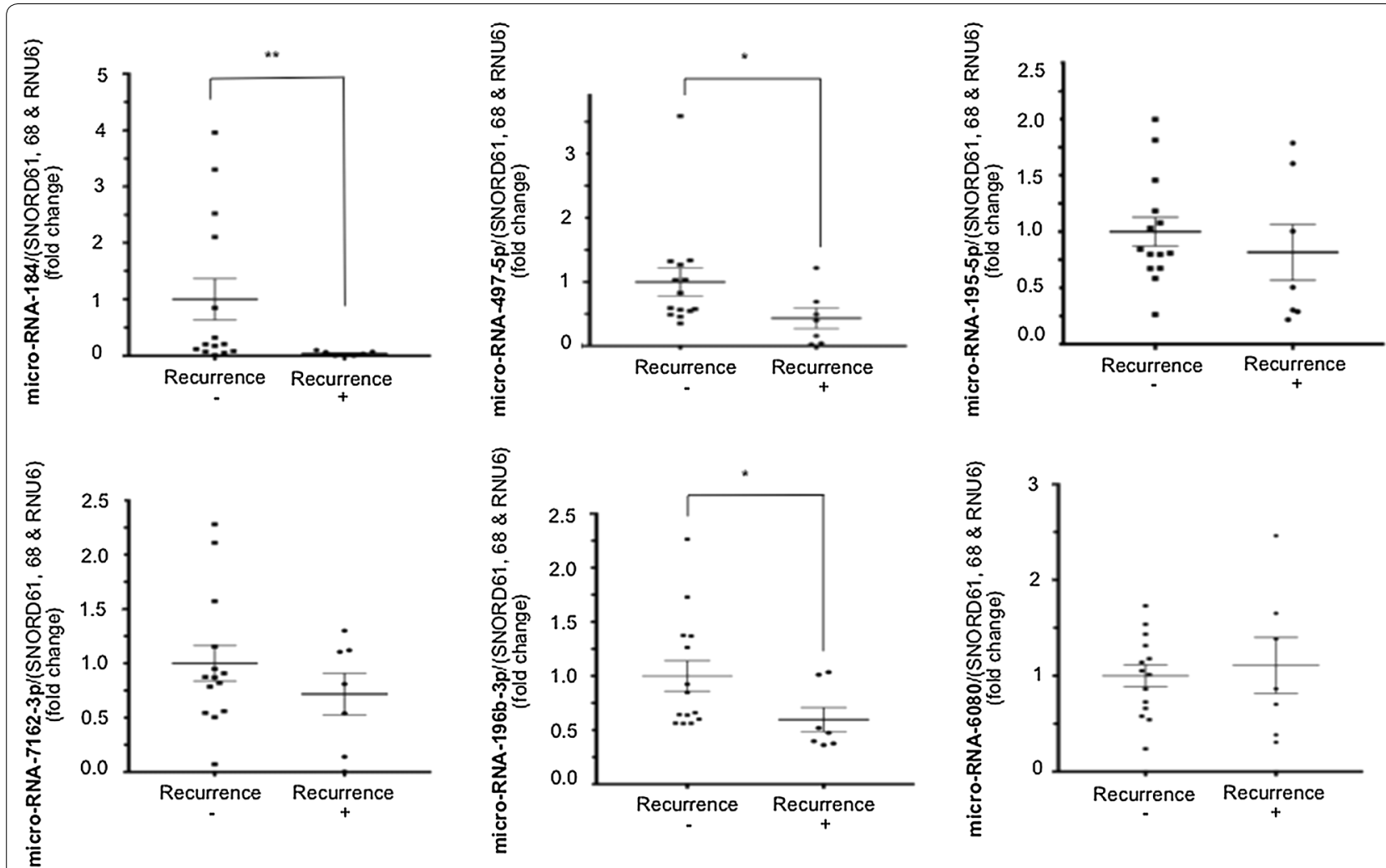

Fig. 4 qRT-PCR assay. The expression levels of 3 microRNAs (micro-RNA-184, micro-RNA-497-5p and micro-RNA-196-3p) were significantly lower in FFPE LREC from R+ women vs. FFPE LREC from R- women. Mann-Whitney test, ${ }^{*} p<0.05$; ** $p<0.001$; mean \pm SEM. FFPE formalin-fixed paraffin-embedded, $L R E C$ low risk endometrial cancer, $R+$ women whose follow up showed recurrence, $R-$ women whose follow up showed no recurrence

\section{Discussion}

Our results show that in LREC, $\mathrm{R}+$ women have different micro-RNA profiles from $\mathrm{R}-$ women. Moreover, we found that recurrence status can be accurately assessed using micro-RNA expression levels on primary FFPE tumor.

The crucial issue in managing patients with early-stage $\mathrm{EC}$ is to determine the risk of recurrence to better adapt the therapeutic strategy. Currently, higher risk of recurrence has been described when early stage EC was associated with histological settings, including myometrial involvement $>50 \%$ [16], histological type 2 and grade 3 tumors [17, 18] and presence of LVSI [19]. However, histological factors such as histological type or LVSI status have been criticized for their lack of reproducibility [20]. Guidelines for therapies widely differ from one country to another [21-25], as they rely on various risk stratification systems (RSS) [3, 19, 21, 22, 26]. Bendifallah et al. in their comparison of five major RSS applied to a multicenter population with early-stage EC, showed that they all have a poor-to-moderate discrimination for recurrence, and are also heterogeneous in terms of classification performance [4]. Over or under estimation of these risks lead to inadequate surgical and adjuvant managements of EC women. This underlines the need for new biological markers, so as to enable a better stratification of women with early stage EC, and thus a better optimization of their treatments and follow up patterns.

Recently, Levine et al. described four molecular EC categories based on integrated genomic, transcriptomic, and proteomic analysis: p53-mutant, microsatellite instability (MSI), POLE-mutant, and no specific molecular profile [27]. Confirmation of the prognostic capacity of these four subgroups in a large randomized trial was provided by Stelloo et al. who studied 834 women from the PORTEC cohorts [28]. However, to our knowledge, there's no study specifically focusing on biomolecular prognosis profile for LREC women. To address this issue, we assessed micro-RNA level expression in primary FFPE specimen of LREC women according to recurrence status. Microarray analysis performed after RNA extraction from 7 FFPE specimens from LREC $\mathrm{R}+$ women matched with 14 FFPE specimens from LREC $\mathrm{R}$ - women showed a significant 

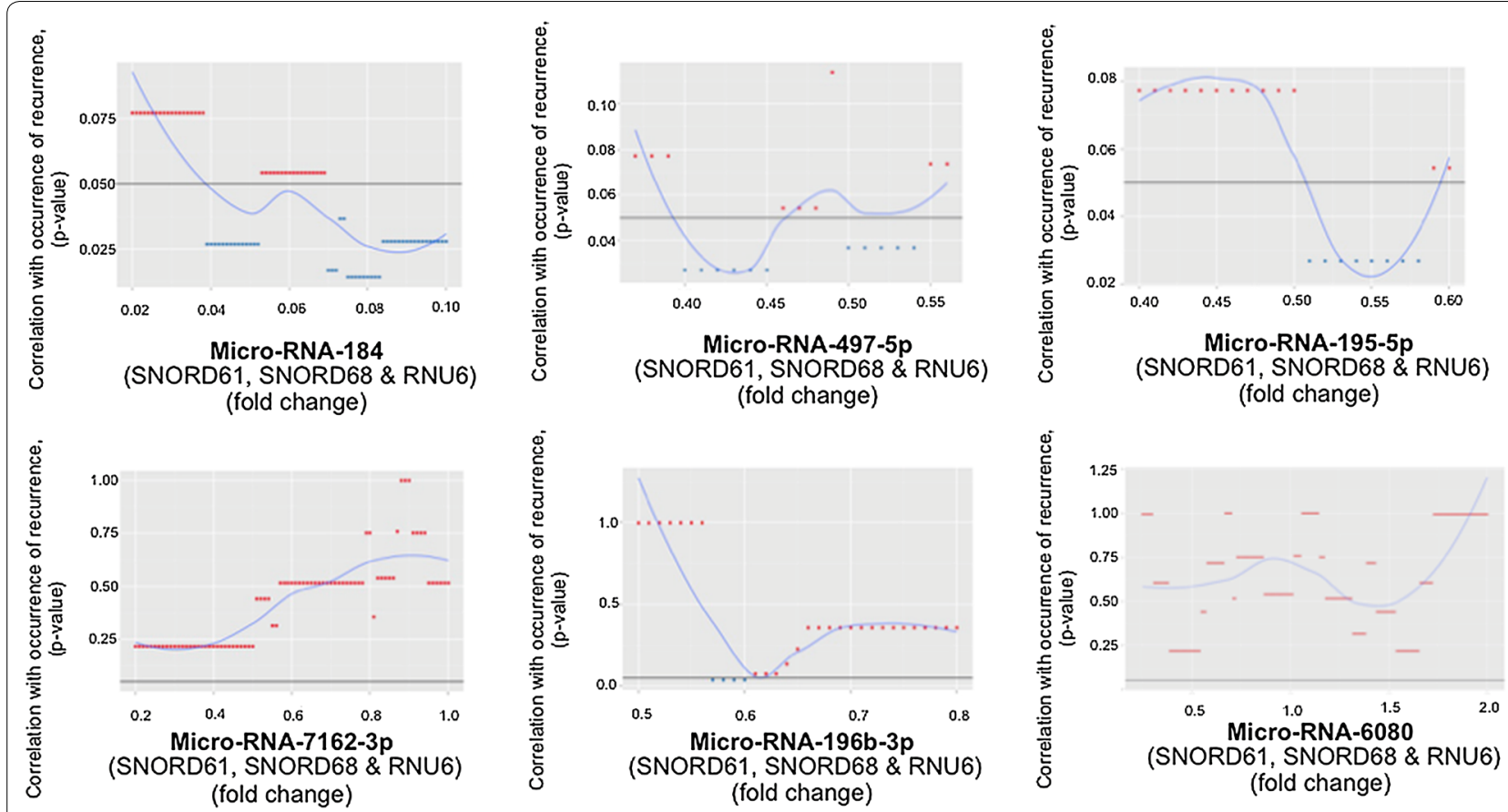

$$
\begin{array}{ll} 
& \text { Significativity } \\
\text { - Non significant }(p \geq 0.05) \\
\text { - Significant }(p<0.05)
\end{array}
$$

Fig. 5 Optimal cut-offs. Optimal cut offs denoting a correlation between micro-RNA expression and the occurrence of recurrence in FFPE LREC from $R+$ patients vs. FFPE LREC from $R$ - patients. FFPE formalin-fixed paraffin-embedded, $L R E C$ low risk endometrial cancer, $R+$ women whose

\begin{tabular}{|c|c|c|c|}
\hline & $\begin{array}{l}\text { EC FFPE } \\
\text { primary tumor } \\
\text { with no recurrence, } \\
\mathrm{N}=14\end{array}$ & $\begin{array}{l}\text { EC FFPE } \\
\text { primary tumor } \\
\text { with recurrence, } \mathrm{N}=7\end{array}$ & $p$-value \\
\hline \multicolumn{4}{|c|}{ Micro-RNA-184 } \\
\hline $\mathrm{FC}<0.083$ & $3(33 \%)$ & $6(66 \%)$ & 0.016 \\
\hline$F C>0.083$ & 11 (92\%) & $1(8 \%)$ & \\
\hline \multicolumn{4}{|c|}{ Micro-RNA-497-5p } \\
\hline$F C<0.45$ & $1(20 \%)$ & $4(80 \%)$ & 0.025 \\
\hline$F C>0.45$ & $13(81 \%)$ & $3(19 \%)$ & \\
\hline \multicolumn{4}{|c|}{ Micro-RNA-195-5p } \\
\hline$F C<0.58$ & $1(20 \%)$ & $4(80 \%)$ & 0.025 \\
\hline$F C>0.58$ & $13(81 \%)$ & $3(19 \%)$ & \\
\hline \multicolumn{4}{|c|}{ Micro-RNA-196-3p } \\
\hline $\mathrm{FC}<0.56$ & $0(0 \%)$ & $5(100 \%)$ & 0.001 \\
\hline$F C>0.56$ & 14 (87\%) & $2(13 \%)$ & \\
\hline
\end{tabular}
follow up showed recurrence, $R$ - women whose follow up showed no recurrence

Table 4 Optimal fold-change cut-offs

LREC low risk endometrial cancer, FFPE formalin-fixed paraffin-embedded, FC fold-change

difference in the expression of 6 micro-RNAs: -184 , -497-5p, 195-5p, -7162-3p, -196b-3p, and -6080. When studying the validated target genes of these microRNAs by enrichment analysis, they all appeared as exclusively involved in carcinogenic pathways, thus reinforcing our analysis. According to literature, microRNAs-184, -497-5p, 195-5p, and -196b-3p had already been described as involved in various cancers, including EC $[9,29,30]$. Furthermore, they have been described associated to the epithelial-to-mesenchymal transition (EMT), which play a key role in cell motility and metastatic spread. The recent discovery of microRNA-7162-3p and micro-RNA-6080 could explain why there are no currently available articles about them. In their review of the current state of science regarding microRNA functionality in EC progression, Stope et al. note that, interestingly, most micro-RNAs in EC cells have been classified as tumor suppressors, with cellular expression being suppressed by malignant processes [31]. This is consistent with our results as 5 microRNAs are under expressed in LREC R+ women with a $\mathrm{FC}>2$ vs. one over expressed.

After validation by RT-qPCR, we found that microRNA-184, -497-5p, and -196b-3p emerged as being 
particularly relevant to determine the occurrence of recurrence in women with LREC.

Micro-RNA-184 has been described as a tumor suppressor in various cancers (lymphoma [32], renal carcinoma [33], breast cancer [34, 35], lung cancer [36, 37], ovarian cancer [38], glioma [39], otorhinolaryngologic cancer [40-42], gastric cancer [43] or adrenocortical tumors [44]). Micro-RNA184 acts by repressing oncogenes such as TNFAIP2 [39, 43], SND1 [45], CDC25A, c-MYC and Bcl-2 [36], and by regulating the AKT/ mTORC1 pathway. In EC, micro-RNA-184 was first described as under expressed by Chung et al. who profiled micro-RNA expression of 30 EC specimen FIGO stage from IA to IIIC, and 22 normal counterparts [29]. More recently, Canlorbe et al. found a strong correlation between level expression of micro-RNA-184 extracted from FFPE specimen of women with grade 1-2 EC and lymph node status [11]. In our study, all included women underwent pelvic nodal staging. They were excluded in case of positive lymph node, as it represents a major bias in the analysis of recurrences. In women with LREC, micro-RNA-184 emerges as an interesting prognostic tool, as its under expression is significantly associated with pelvic lymph node metastasis and/or recurrences.

Similarly, a decreased expression of micro-RNA-497-5p is associated to multiple myeloma [46], thyroid cancer [47], colorectal cancer [48, 49], cervical cancer [50], glioma [51], ovarian cancer [52, 53], breast cancer [54$56]$, bladder cancer $[57,58]$, hepatocellular carcinoma $[59,60]$, otorhinolaryngologic cancer $[61,62]$, pancreas cancer [63], prostate cancer [64], lung cancer [65], renal cancer [66], gastric cancer [67], melanoma [68] or astrocytoma [69]. Various studies showed that over expression of micro-RNA-497 can suppress cell proliferation and induces apoptosis through targeting paired box 3 [46], paired box 2 [52] and YAP1 [59], suppress EMT and metastasis by targeting fos related antigen-1 [48] or vascular endothelial growth factor-A [49], and reduce tumor growth and invasion by suppressing BDNF [47].

Finally, micro-RNA-196 is a known emerging biomarker for digestive tract cancers, where it plays the role of an onco-miR, as it is consistently found over expressed in digestive tract cancer tissues [70-73]. It has also been described as up regulated in otorhinolaryngologic cancer [74], glioblastoma [75], lung cancer [76], ovarian cancer [77] or osteosarcoma [78]. On the other hand, micro-RNA-196 down regulation is implicated in homeobox B7-vascular endothelial growth factor pathway, which plays an important role in cervical cancer progression [79]. It was also described as down regulated among 54 other micro-RNAs in endometrial serous carcinoma compared to normal endometrial tissue [30]. Abe et al., in their study on the global expression pattern of
micro-RNA in endometriotic stroma cells, found that expression of micro-RNA-196b in endometriotic cyst stromal cells is repressed by DNA hyper methylation of the micro-RNA-196b gene, which may be involved in the development of proliferative and anti-apoptotic characteristics of endometriosis [80].

Both micro-RNA-184 and -196 have been described as tumor genesis marker. Indeed, MicroRNA 184 was also described as significantly downregulated in tissues from patients with colorectal cancer, ovarian cancer or prostate carcinoma, compared with matched normal adjacent tissues [38, 81, 82]. It was also differentially expressed in glioma tissues compared to normal brain tissues [83], and in tongue carcinomas tissues compared to paired normal tissues [84]. Micro-RNA-196 was differentially expressed in pancreatic resection specimens from carcinoma cases and its precursors vs. benign pancreatic specimens [85], in oral squamous cell carcinoma tissues (OSCC) vs. contral mucosa [86], in breast cancer samples vs. normal breast samples [87] and in colonic cancer specimens vs. para-cancerous specimens [88]. But both of them have also been described as associated with tumor recurrence, in granulosa tumors for micro-RNA-184 [89] and in OSCC for micro-RNA-196 [86]. Unfortunately, the design of our study didn't include normal adjacent tissues nor blood samples. To confirm that these selected microRNAs are involved not only in tumor genesis but also in recurrences, further studies comparing their expression in LREC and normal sample should be completed.

In our study, we focused on post-operative FFPE EC specimen, since it is known that FFPE tumors can be used for RT-PCR-based quantitative micro-RNA profiling [9]. This enabled us to work on samples taken between 2000 and 2014, and selected among the entire specimen collections of the Pathology Departments. In the aim of optimizing the adjuvant management and the follow up of the women, working on post-operative specimen is not a problem. However, to provide a preoperative diagnostic tool so as to better stratify women and to optimize their surgical procedures, our analysis should be validated before initial surgery. To do so, two options can be considered: the first one is to assess micro-RNA expression in pre-operative tumor biopsy samples, the second one is to work on preoperative blood samples. Studying micro-RNA expression profiles on biopsy samples comes with a risk of contamination of normal endometrial or myometrial tissue, which could lead to a wrong analysis. Interestingly, several authors have demonstrated that circulating micro-RNA profiles extracted from plasma samples were correlated with profiles extracted from FFPE specimen [90]. In EC, various studies have demonstrated that circulating micro-RNA could be used as diagnostic 
tools for endometrioid EC (micro-RNA-15b, -27a, and -233, and micro-RNA-9/micro-RNA-1228 and microRNA-9/micro-RNA-92a respectively [91, 92]). MicroRNA-184, -497, and -196b-3p, have been described in various cancer as promising diagnosis tools preoperatively assessed in blood samples [34, 44, 50, 58, 69, $73,93,94]$. Owing to their significant implication in EC progression, they may be promising tools of diagnosis, prognosis and treatment response. Micro-RNA 184, who was studied in numerous cancers, appears as a serious candidate for future researches. Although recent technology improvements may allow microRNA-184 detection and quantification easily from clinical samples, further investigations are still needed first to assess the exact role of this micro-RNA in endometrial carcinogenesis, second to precise its interactions with the other selected microRNA and third to prove the correlation between blood samples and tumor samples in patients with endometrial cancer.

Some limitations of the study should be underlined. Because of the use of FFPE specimens with insufficient quality and RNA integrity, we could not assess the expression of exact targets for the micro-RNAs validated in this study. Further studies are thus needed to precisely determine the different pathways affected by the selected micro-RNAs. Second, we included patients with both local and distance recurrence that have different long-term prognosis. Indeed, recently, Ouldamer et al. demonstrated that patients recurring under the form of distant metastasis or carcinomatosis had poorer prognosis [95]. Moreover, from clinical point of view this difference is relevant, as patients with local recurrence could have benefited from external beam radiotherapy while patients with distant metastasis or carcinomatosis could have benefited of adjuvant chemotherapy. Third, due to the sample size, it was impossible to determine a combination of micro-RNAs allowing the detection of all $\mathrm{R}+$ patients. Future research is needed to resolve this problem. Finally, the retrospective nature of our data collection, which was focused on the occurrence of recurrence, should be underlined as a possible bias.

\section{Conclusion}

This is, to our knowledge, the first study investigating a correlation between micro-RNA signatures in tumor tissues from LREC women and the occurrence of recurrences.

Our results may provide a basis for further study of the micro-RNA function EC, and be used as a valuable tool for better diagnostic and therapeutic management.

\section{Abbreviations}

EC: endometrial cancer; EMT: epithelial to mesenchymal transition; ESMO: European Society for Medical Oncology; FC: fold change; FFPE: formalin-fixed paraffin-embedded; FIGO: International Federation of Gynecology and Obstetrics; GO: gene ontology; IQR: interquartile range; LREC: low risk endometrial cancer; LVSI: lympho vascular space involvement; qRT-PCR: quantitative realtime PCR; R- women: women whose follow up did not show any recurrence; R+ women: women whose follow up showed recurrences; RFS: recurrence free survival; RT: reverse transcription.

\section{Authors' contributions}

Conceived and designed the experiments: TF, SB, MB, ED, CM, CT, SA, CU, GC. Performed the experiments: TF, MS, RF, GC. Analyzed the data: TF, CM, GC. Contributed reagents/materials/analysis tools: TF, MS, ML, IAA, RM, BH, NCB. Manuscript preparation: all the authors. Manuscript editing: all the authors. Manuscript review: all the authors. All authors read and approved the final manuscript.

\section{Author details}

${ }^{1}$ INSERM, UMR S 938, Sorbonne University, Paris, France. ${ }^{2}$ Department of Obstetrics and Gynaecology, Tenon University Hospital, Assistance Publique des Hôpitaux de Paris, Sorbonne University, Paris, France. ${ }^{3}$ Department of Obstetrics and Gynaecology, Creteil Intercommunal Hospital, Université Paris Est, Paris XII, Créteil, France. ${ }^{4}$ INSERM, UMR S 707, Sorbonne University, Paris, France. ${ }^{5}$ Department of Pathology, Tenon University Hospital, Assistance Publique des Hôpitaux de Paris, Sorbonne University, Paris, France. ${ }^{6}$ Department of Dermatology, Cochin University Hospital, Assistance Publique des Hôpitaux de Paris, University René Descartes, Paris, France. ${ }^{7}$ Department of Surgery and Oncological Gynaecology, Pitié-Salpétrière University Hospital, Assistance Publique des Hôpitaux de Paris, Sorbonne University, Paris, France. ${ }^{8}$ Institut Universitaire de Cancérologie (IUC), Paris, France. ${ }^{9}$ Department of Pathology, Creteil Intercommunal Hospital, Université Paris Est, Paris XII, Créteil, France. ${ }^{10}$ Cochin Institute, Inserm U1016, CNRS 8104, University René Descartes, Paris, France. ${ }^{11}$ INSERM, UMR U965, Paris Diderot University, Paris, France.

\section{Acknowledgements}

We thank Sebastien Jacques (Plateforme Genomic, INSERM U1016, Institut Cochin), and Michèle Oster (UMRS 938) for expert contributions.

\section{Competing interests}

The authors declare that they have no competing interests.

\section{Availability of data and materials}

Microarray hybridization results are available on Gene Expression Omnibus (GEO: GSE100078). The datasets generated and analysed during the current study are not publicly available but are available from the corresponding author on reasonable request.

\section{Consent for publication}

All included patients consent to the publication of their data.

\section{Ethics approval and consent to participate}

Approval for the present study was obtained from the local Medical Ethics Committee (CPP Ile-de-France X; 2015-01-03). All included patients consent to the use of their data.

\section{Funding}

No external source of funding was used for this study.

\section{Publisher's Note}

Springer Nature remains neutral with regard to jurisdictional claims in published maps and institutional affiliations.

Received: 1 February 2018 Accepted: 12 May 2018

Published online: 21 May 2018 


\section{References}

1. Ferlay J, Soerjomataram I, Dikshit R, Eser S, Mathers C, Rebelo M, et al. Cancer incidence and mortality worldwide: sources, methods and major patterns in GLOBOCAN 2012. Int J Cancer. 2015;136(5):E359-86.

2. Siegel RL, Miller KD, Jemal A. Cancer statistics, 2015. CA Cancer J Clin. 2015;65(1):5-29.

3. Colombo N, Preti E, Landoni F, Carinelli S, Colombo A, Marini C, et al. Endometrial cancer: ESMO clinical practice guidelines for diagnosis, treatment and follow-up. Ann Oncol. 2013:24(Suppl 6):vi33-8.

4. Bendifallah $S$, Canlorbe $G$, Collinet $P$, Arsène $E$, Huguet $F$, Coutant $C$, et al. Just how accurate are the major risk stratification systems for early-stage endometrial cancer? Br J Cancer. 2015;112(5):793.

5. Creutzberg CL, van Putten WL, Koper PC, Lybeert ML, Jobsen JJ, WárlámRodenhuis CC, et al. Surgery and postoperative radiotherapy versus surgery alone for patients with stage- 1 endometrial carcinoma: multicentre randomised trial. Lancet. 2000;355(9213):1404-11.

6. O'Hara AJ, Bell DW. The genomics and genetics of endometrial cancer. Adv Genomics Genet. 2012:2:33.

7. Guo H, Ingolia NT, Weissman JS, Bartel DP. Mammalian microRNAs predominantly act to decrease target mRNA levels. Nature. 2010;466(7308):835

8. Farazi TA, Hoell J, Morozov P, Tuschl T. microRNAs in human cancer. Adv Exp Med Biol. 2013;774:1

9. Tsukamoto O, Miura K, Mishima H, Abe S, Kaneuchi M, Higashijima A, et al. Identification of endometrioid endometrial carcinoma-associated microRNAs in tissue and plasma. Gynecol Oncol. 2014;132(3):715-21.

10. Canlorbe G, Castela M, Bendifallah S, Wang Z, Lefevre M, Chabbert-Buffet $\mathrm{N}$, et al. Micro-RNA signature of lymphovascular space involvement in type 1 endometrial cancer. Histol Histopathol. 2016:32:11859.

11. Canlorbe G, Wang Z, Laas E, Bendifallah S, Castela M, Lefevre M, et al. Identification of microRNA expression profile related to lymph node status in women with early-stage grade 1-2 endometrial cancer. Mod Pathol. 2016;29(4):391-401.

12. Moreno-Moya JM, Vilella F, Simón C. MicroRNA: key gene expression regulators. Fertil Steril. 2014;101(6):1516-23.

13. Bendifallah S, Ouldamer L, Lavoue V, Canlorbe G, Raimond E, Coutant C, et al. Patterns of recurrence and outcomes in surgically treated women with endometrial cancer according to ESMO-ESGO-ESTRO Consensus Conference risk groups: results from the FRANCOGYN study Group. Gynecol Oncol. 2017;144(1):107-12.

14. Chen EY, Tan CM, Kou Y, Duan Q, Wang Z, Meirelles GV, et al. Enrichr: interactive and collaborative HTML5 gene list enrichment analysis tool. BMC Bioinform. 2013;14:128.

15. Kuleshov MV, Jones MR, Rouillard AD, Fernandez NF, Duan Q, Wang Z, et al. Enrichr: a comprehensive gene set enrichment analysis web server 2016 update. Nucleic Acids Res. 2016:44(W1):W90-7.

16. Mariani A, Webb MJ, Keeney GL, Lesnick TG, Podratz KC. Surgical stage I endometrial cancer: predictors of distant failure and death. Gynecol Oncol. 2002:87(3):274-80.

17. Nugent EK, Bishop EA, Mathews CA, Moxley KM, Tenney M, Mannel RS, et al. Do uterine risk factors or lymph node metastasis more significantly affect recurrence in patients with endometrioid adenocarcinoma? Gynecol Oncol. 2012;125(1):94-8.

18. Creasman WT, Morrow CP, Bundy BN, Homesley HD, Graham JE, Heller PB. Surgical pathologic spread patterns of endometrial cancer. A Gynecologic Oncology Group Study. Cancer. 1987;60(8 Suppl):2035-41.

19. Bendifallah S, Canlorbe G, Raimond E, Hudry D, Coutant C, Graesslin $\mathrm{O}$, et al. A clue towards improving the European Society of Medical Oncology risk group classification in apparent early stage endometrial cancer? Impact of lymphovascular space invasion. Br J Cancer. 2014;110(11):2640-6.

20. Nordström B, Strang P, Lindgren A, Bergström R, Tribukait B. Carcinoma of the endometrium: do the nuclear grade and DNA ploidy provide more prognostic information than do the FIGO and WHO classifications? Int Gynecol Pathol. 1996;15(3):191-201.

21. Creutzberg CL, van Putten WL, Koper PC, Lybeert ML, Jobsen JJ, WárlámRodenhuis CC, et al. Surgery and postoperative radiotherapy versus surgery alone for patients with stage-1 endometrial carcinoma: multicentre randomised trial. PORTEC Study Group. Post Operative Radiation Therapy in Endometrial Carcinoma. Lancet Lond Engl. 2000;355(9213):1404-11.
22. Keys HM, Roberts JA, Brunetto VL, Zaino RJ, Spirtos NM, Bloss JD, et al. A phase III trial of surgery with or without adjunctive external pelvic radiation therapy in intermediate risk endometrial adenocarcinoma: a Gynecologic Oncology Group study. Gynecol Oncol. 2004;92(3):744-51.

23. Colombo N, Creutzberg C, Amant F, Bosse T, González-Martín A, Ledermann J, et al. ESMO-ESGO-ESTRO consensus conference on endometrial cancer: diagnosis, treatment and follow-up. Ann Oncol. 2016:27(1):16-41.

24. ASTEC study group, Kitchener H, Swart AMC, Qian Q, Amos C, Parmar MKB. Efficacy of systematic pelvic lymphadenectomy in endometrial cancer (MRC ASTEC trial): a randomised study. Lancet Lond Engl. 2009;373(9658):125-36.

25. Ko EM, Funk MJ, Clark LH, Brewster WR. Did GOG99 and PORTEC1 change clinical practice in the United States? Gynecol Oncol. 2013;129(1):12-7.

26. Todo Y, Kato H, Kaneuchi M, Watari H, Takeda M, Sakuragi N. Survival effect of para-aortic lymphadenectomy in endometrial cancer (SEPAL study): a retrospective cohort analysis. Lancet Lond Engl. 2010;375(9721):1165-72.

27. Cancer Genome Atlas Research Network, Kandoth C, Schultz N, Cherniack AD, Akbani R, Liu Y, et al. Integrated genomic characterization of endometrial carcinoma. Nature. 2013;497(7447):67-73.

28. Stelloo E, Nout RA, Osse EM, Jürgenliemk-Schulz IJ, Jobsen JJ, Lutgens LC, et al. Improved risk assessment by integrating molecular and clinicopathological factors in early-stage endometrial cancer-combined analysis of the PORTEC cohorts. Clin Cancer Res. 2016;22(16):4215-24

29. Chung TKH, Cheung T-H, Huen N-Y, Wong KWY, Lo KWK, Yim S-F, et al. Dysregulated microRNAs and their predicted targets associated with endometrioid endometrial adenocarcinoma in Hong Kong women. Int J Cancer. 2009:124(6):1358-65.

30. Hiroki E, Akahira J, Suzuki F, Nagase S, Ito K, Suzuki T, et al. Changes in microRNA expression levels correlate with clinicopathological features and prognoses in endometrial serous adenocarcinomas. Cancer Sci. 2010;101(1):241-9.

31. Stope MB, Koensgen D, Weimer J, Paditz M, Burchardt M, Bauerschlag D, et al. The future therapy of endometrial cancer: microRNA's functionality, capability, and putative clinical application. Arch Gynecol Obstet. 2016;294(5):889-95.

32. Liang X-G, Meng W-T, Hu L-J, Li L, Xing H, Xie G, et al. MicroRNA-184 modulates human central nervous system lymphoma cells growth and invasion by targeting iASPP. J Cell Biochem. 2016;118:1645-53.

33. Huang J, Kong W, Zhang J, Chen Y, Xue W, Liu D, et al. c-Myc modulates glucose metabolism via regulation of miR-184/PKM2 pathway in clearcell renal cell carcinoma. Int J Oncol. 2016;49(4):1569-75.

34. Fu L, Li Z, Zhu J, Wang P, Fan G, Dai Y, et al. Serum expression levels of microRNA-382-3p, -598-3p, -1246 and -184 in breast cancer patients. Oncol Lett. 2016;12(1):269-74.

35. Phua YW, Nguyen A, Roden DL, Elsworth B, Deng N, Nikolic I, et al. MicroRNA profiling of the pubertal mouse mammary gland identifies miR-184 as a candidate breast tumour suppressor gene. BCR. 2015;17:83

36. Lin T-C, Lin P-L, Cheng Y-W, Wu T-C, Chou M-C, Chen C-Y, et al. MicroRNA-184 deregulated by the MicroRNA-21 promotes tumor malignancy and poor outcomes in non-small cell lung cancer via targeting CDC25A and c-Myc. Ann Surg Oncol. 2015;22:1532-9.

37. Wu S, Shen W, Pan Y, Zhu M, Xie K, Geng L, et al. Genetic variations in key MicroRNAs are associated with the survival of nonsmall cell lung cancer. Medicine (Baltimore). 2015;94(47):e2084.

38. Qin C-Z, Lou X-Y, Lv Q-L, Cheng L, Wu N-Y, Hu L, et al. MicroRNA-184 acts as a potential diagnostic and prognostic marker in epithelial ovarian cancer and regulates cell proliferation, apoptosis and inflammation. Pharm. 2015;70(10):668-73.

39. Cheng Z, Wang HZ, Li X, Wu Z, Han Y, Li Y, et al. MicroRNA-184 inhibits cell proliferation and invasion, and specifically targets TNFAIP2 in Glioma. J Exp Clin Cancer Res. 2015;34:27.

40. Manikandan M, Deva Magendhra Rao AK, Rajkumar KS, Rajaraman R, Munirajan AK. Altered levels of miR-21, miR-125b-2*, miR-138, miR-155, miR-184, and miR-205 in oral squamous cell carcinoma and association with clinicopathological characteristics. J Oral Pathol Med. 2015:44(10):792-800.

41. Zhen Y, Liu Z, Yang H, Yu X, Wu Q, Hua S, et al. Tumor suppressor PDCD4 modulates miR-184-mediated direct suppression of C-MYC and BCL2 blocking cell growth and survival in nasopharyngeal carcinoma. Cell Death Dis. 2013;4:e872. 
42. Santhi WS, Prathibha R, Charles S, Anurup KG, Reshmi G, Ramachandran S, et al. Oncogenic microRNAs as biomarkers of oral tumorigenesis and minimal residual disease. Oral Oncol. 2013;49(6):567-75.

43. Xu Y, Ma H, Yu H, Liu Z, Wang L-E, Tan D, et al. The miR-184 binding-site rs8126 T>C polymorphism in TNFAIP2 is associated with risk of gastric cancer. PLOS ONE. 2013;8(5):e64973.

44. Szabó DR, Luconi M, Szabó PM, Tóth M, Szücs N, Horányi J, et al. Analysis of circulating microRNAs in adrenocortical tumors. Lab Investig J Tech Methods Pathol. 2014:94(3):331-9.

45. Emdad L, Janjic A, Alzubi MA, Hu B, Santhekadur PK, Menezes ME, et al. Suppression of miR-184 in malignant gliomas upregulates SND1 and promotes tumor aggressiveness. Neuro-Oncol. 2015;17(3):419-29.

46. Yu T, Zhang $X$, Zhang $L$, Wang $Y$, Pan $H, X u Z$, et al. MicroRNA-497 suppresses cell proliferation and induces apoptosis through targeting PBX3 in human multiple myeloma. Am J Cancer Res. 2016;6(12):2880-9.

47. Wang P, Meng X, Huang Y, Lv Z, Liu J, Wang G, et al. MicroRNA-497 inhibits thyroid cancer tumor growth and invasion by suppressing BDNF. Oncotarget. 2017;8(2):2825-34.

48. Zhang N, Shen Q, Zhang P. miR-497 suppresses epithelial-mesenchymal transition and metastasis in colorectal cancer cells by targeting fos-related antigen-1. OncoTargets Ther. 2016;9:6597-604.

49. Qiu Y, Yu H, Shi X, Xu K, Tang Q, Liang B, et al. microRNA-497 inhibits invasion and metastasis of colorectal cancer cells by targeting vascular endothelial growth factor-A. Cell Prolif. 2016;49(1):69-78.

50. Zhang Y, Zhang D, Wang F, Xu D, Guo Y, Cui W. Serum miRNAs panel (miR-16-2*, miR-195, miR-2861, miR-497) as novel non-invasive biomarkers for detection of cervical cancer. Sci Rep. 2015;5:17942.

51. Feng F, Kuai D, Wang H, Li T, Miao W, Liu Y, et al. Reduced expression of microRNA-497 is associated with greater angiogenesis and poor prognosis in human gliomas. Hum Pathol. 2016;58:47-53.

52. Lin Z, Zhao J, Wang X, Zhu X, Gong L. Overexpression of microRNA-497 suppresses cell proliferation and induces apoptosis through targeting paired box 2 in human ovarian cancer. Oncol Rep. 2016;36(4):2101-7.

53. Xu S, Fu G-B, Tao Z, OuYang J, Kong F, Jiang B-H, et al. MiR-497 decreases cisplatin resistance in ovarian cancer cells by targeting mTOR/P70S6K1. Oncotarget. 2015;6(28):26457-71.

54. Han L, Liu B, Jiang L, Liu J, Han S. MicroRNA-497 downregulation contributes to cell proliferation, migration, and invasion of estrogen receptor alpha negative breast cancer by targeting estrogen-related receptor alpha. Tumour Biol. 2016;37(10):13205-14.

55. Liu J, Zhou Y, Shi Z, Hu Y, Meng T, Zhang X, et al. microRNA-497 modulates breast cancer cell proliferation, invasion, and survival by targeting SMAD7. DNA Cell Biol. 2016;35(9):521-9.

56. Wu Z, Li X, Cai X, Huang C, Zheng M. miR-497 inhibits epithelial mesenchymal transition in breast carcinoma by targeting Slug. Tumour Biol. 2016;37(6):7939-50.

57. Zhang Y, Zhang Z, Li Z, Gong D, Zhan B, Man X, et al. MicroRNA-497 inhibits the proliferation, migration and invasion of human bladder transitional cell carcinoma cells by targeting E2F3. Oncol Rep. 2016:36(3):1293-300

58. Nagata M, Muto S, Horie S. Molecular biomarkers in bladder cancer: novel potential indicators of prognosis and treatment outcomes. Dis Markers. 2016;2016:8205836.

59. Zhang L, Yu Z, Xian Y, Lin X. microRNA-497 inhibits cell proliferation and induces apoptosis by targeting YAP1 in human hepatocellular carcinoma. FEBS Open Bio. 2016;6(2):155-64.

60. Ding W-Z, Ni Q-F, Lu Y-T, Kong L-L, Yu J-J, Tan L-W, et al. MicroRNA-497 regulates cell proliferation in hepatocellular carcinoma. Oncol Lett. 2016:11(2):1081-8.

61. Wong N, Khwaja SS, Baker CM, Gay HA, Thorstad WL, Daly MD, et al. Prognostic microRNA signatures derived from the cancer genome Atlas for head and neck squamous cell carcinomas. Cancer Med. 2016;5(7):1619-28.

62. Wang S, Mo Y, Midorikawa K, Zhang Z, Huang G, Ma N, et al. The potent tumor suppressor miR-497 inhibits cancer phenotypes in nasopharyngeal carcinoma by targeting ANLN and HSPA4L. Oncotarget. 2015;6(34):35893-907.

63. Liu A, Huang C, Cai X, Xu J, Yang D. Twist promotes angiogenesis in pancreatic cancer by targeting miR-497/NEGFA axis. Oncotarget. 2016:7(18):25801-14.
64. Wu D, Niu X, Pan H, Zhang Z, Zhou Y, Qu P, et al. MicroRNA-497 targets hepatoma-derived growth factor and suppresses human prostate cancer cell motility. Mol Med Rep. 2016;13(3):2287-92.

65. Gu A, Lu J, Wang W, Shi C, Han B, Yao M. Role of miR-497 in VEGF-A-mediated cancer cell growth and invasion in non-small cell lung cancer. Int J Biochem Cell Biol. 2016;70:118-25.

66. Zhao X, Zhao Z, Xu W, Hou J, Du X. Down-regulation of miR-497 is associated with poor prognosis in renal cancer. Int J Clin Exp Pathol. 2015:8(1):758-64

67. Li W, Jin X, Deng X, Zhang G, Zhang B, Ma L. The putative tumor suppressor microRNA-497 modulates gastric cancer cell proliferation and invasion by repressing elF4E. Biochem Biophys Res Commun. 2014;449(2):235-40.

68. Kunz M. MicroRNAs in melanoma biology. Adv Exp Med Biol. 2013;774:103-20

69. Yang C, Wang C, Chen X, Chen S, Zhang Y, Zhi F, et al. Identification of seven serum microRNAs from a genome-wide serum microRNA expression profile as potential noninvasive biomarkers for malignant astrocytomas. Int J Cancer. 2013;132(1):116-27.

70. Shen S, Pan J, Lu X, Chi P. Role of miR-196 and its target gene HoxB8 in the development and proliferation of human colorectal cancer and the impact of neoadjuvant chemotherapy with FOLFOX4 on their expression. Oncol Lett. 2016;12(5):4041-7.

71. Lu Y-C, Chang JT, Chan E-C, Chao Y-K, Yeh T-S, Chen J-S, et al. miR-196, an emerging cancer biomarker for digestive tract cancers. J Cancer. 2016;7(6):650-5.

72. Amin M, Lam AK. Current perspectives of mi-RNA in oesophageal adenocarcinoma: roles in predicting carcinogenesis, progression and values in clinical management. Exp Mol Pathol. 2015;98(3):411-8.

73. Tsai M-M, Wang C-S, Tsai C-Y, Huang C-G, Lee K-F, Huang H-W, et al. Circulating microRNA-196a/b are novel biomarkers associated with metastatic gastric cancer. Eur J Cancer Oxf Engl. 2016;64:137-48.

74. Lu Y-C, Chang JT, Liao C-T, Kang C-J, Huang S-F, Chen I-H, et al. OncomiR-196 promotes an invasive phenotype in oral cancer through the NME4-JNK-TIMP1-MMP signaling pathway. Mol Cancer. 2014;13:218.

75. Guan Y, Mizoguchi M, Yoshimoto K, Hata N, Shono T, Suzuki SO, et al. MiRNA-196 is upregulated in glioblastoma but not in anaplastic astrocytoma and has prognostic significance. Clin Cancer Res Off J Am Assoc Cancer Res. 2010;16(16):4289-97.

76. Yu S-L, Lee DC, Sohn HA, Lee SY, Jeon HS, Lee JH, et al. Homeobox A9 directly targeted by miR-196b regulates aggressiveness through nuclear factor-kappa B activity in non-small cell lung cancer cells. Mol Carcinog. 2016;55(12):1915-26.

77. Chong GO, Jeon H-S, Han HS, Son JW, Lee YH, Hong DG, et al. Differential MicroRNA expression profiles in primary and recurrent epithelial ovarian cancer. Anticancer Res. 2015;35(5):2611-7.

78. Zhang C, Yao C, Li H, Wang G, He X. Combined elevation of microRNA$196 \mathrm{a}$ and microRNA-196b in sera predicts unfavorable prognosis in patients with osteosarcomas. Int J Mol Sci. 2014;15(4):6544-55.

79. How C, Hui ABY, Alajez NM, Shi W, Boutros PC, Clarke BA, et al. MicroRNA$196 \mathrm{~b}$ regulates the homeobox B7-vascular endothelial growth factor axis in cervical cancer. PLoS ONE. 2013;8(7):e67846.

80. Abe W, Nasu K, Nakada C, Kawano Y, Moriyama M, Narahara H. miR196b targets c-myc and Bcl-2 expression, inhibits proliferation and induces apoptosis in endometriotic stromal cells. Hum Reprod Oxf Engl. 2013;28(3):750-61.

81. Wu G, Liu J, Wu Z, Wu X, Yao X. MicroRNA-184 inhibits cell proliferation and metastasis in human colorectal cancer by directly targeting IGF-1R. Oncol Lett. 2017;14(3):3215-22.

82. Schaefer A, Jung M, Mollenkopf H-J, Wagner I, Stephan C, Jentzmik F, et al Diagnostic and prognostic implications of microRNA profiling in prostate carcinoma. Int J Cancer. 2010;126(5):1166-76.

83. Wu X-B, Yang W, Fan G, Lin W-R, Liu F, Lu Z-M. Expression of microRNA-184 in glioma. Oncol Lett. 2018;15(1):727-30.

84. Wong T-S, Liu X-B, Wong BY-H, Ng RW-M, Yuen AP-W, Wei WI. Mature miR184 as potential oncogenic microRNA of squamous cell carcinoma of tongue. Clin Cancer Res Off J Am Assoc Cancer Res. 2008;14(9):2588-92.

85. Xue Y, Abou Tayoun AN, Abo KM, Pipas JM, Gordon SR, Gardner TB, et al. MicroRNAs as diagnostic markers for pancreatic ductal adenocarcinoma and its precursor, pancreatic intraepithelial neoplasm. Cancer Genet. 2013;206(6):217-21. 
86. Liu C-J, Tsai M-M, Tu H-F, Lui M-T, Cheng H-W, Lin S-C. miR-196a overexpression and miR-196a2 gene polymorphism are prognostic predictors of oral carcinomas. Ann Surg Oncol. 2013;20(Suppl 3):S406-14.

87. Hui ABY, Shi W, Boutros PC, Miller N, Pintilie M, Fyles T, et al. Robust global micro-RNA profiling with formalin-fixed paraffin-embedded breast cancer tissues. Lab Investig J Tech Methods Pathol. 2009;89(5):597-606.

88. Wang YX, Zhang XY, Zhang BF, Yang CQ, Chen XM, Gao HJ. Initial study of microRNA expression profiles of colonic cancer without lymph node metastasis. J Dig Dis. 2010;11(1):50-4.

89. Cheng W-T, Rosario R, Muthukaruppan A, Wilson MK, Payne K, Fong PC, et al. MicroRNA profiling of ovarian granulosa cell tumours reveals novel diagnostic and prognostic markers. Clin Epigenetics. 2017;9:72.

90. Xu L, Li M, Wang M, Yan D, Feng G, An G. The expression of microRNA-375 in plasma and tissue is matched in human colorectal cancer. BMC Cancer. 2014;14:714.

91. Wang L, Chen $Y-J, X u K, X u H$, Shen X-Z, Tu R-Q. Circulating microRNAs as a fingerprint for endometrial endometrioid adenocarcinoma. PLOS ONE. 2014;9(10):e110767.
92. Torres A, Torres K, Pesci A, Ceccaroni M, Paszkowski T, Cassandrini P, et al. Diagnostic and prognostic significance of miRNA signatures in tissues and plasma of endometrioid endometrial carcinoma patients. Int J Cancer. 2013;132(7):1633-45.

93. Pang P-C, Shi X-Y, Huang W-L, Sun K. miR-497 as a potential serum biomarker for the diagnosis and prognosis of osteosarcoma. Eur Rev Med Pharmacol Sci. 2016;20(18):3765-9.

94. Hernandez YG, Lucas AL. MicroRNA in pancreatic ductal adenocarcinoma and its precursor lesions. World J Gastrointest Oncol. 2016:8(1):18-29.

95. Ouldamer L, Bendifallah S, Body G, Touboul C, Graesslin O, Raimond E, et al. Predicting poor prognosis recurrence in women with endometrial cancer: a nomogram developed by the FRANCOGYN study group. Br J Cancer. 2016;115(11):1296-303.
Ready to submit your research? Choose BMC and benefit from:

- fast, convenient online submission

- thorough peer review by experienced researchers in your field

- rapid publication on acceptance

- support for research data, including large and complex data types

- gold Open Access which fosters wider collaboration and increased citations

- maximum visibility for your research: over $100 \mathrm{M}$ website views per year

At BMC, research is always in progress.

Learn more biomedcentral.com/submissions 